\title{
Inverse model analysis of the planktonic food web of Takapoto Atoll (French Polynesia)
}

\author{
Nathalie Niquil ${ }^{1, *}$, George A. Jackson ${ }^{2}$, Louis Legendre ${ }^{3}$, Bruno Delesalle ${ }^{1}$ \\ ${ }^{1}$ EPHE, Laboratoire de Biologie Marine et Malacologie, URA CNRS 1453, Université de Perpignan, \\ F-66860 Perpignan Cedex, France; and CRIOBE, BP 1013 Moorea, Polynésie française \\ ${ }^{2}$ Department of Oceanography, Texas A\&M University, College Station, Texas 77843, USA \\ ${ }^{3}$ Département de biologie, Université Laval, Québec G1K 7P4, Canada
}

\begin{abstract}
A steady-state model of the planktonic food web of the lagoon of Takapoto Atoll (Tuamotu Archipelago, French Polynesia) was developed to assess the characteristics of that ecosystem. The planktonic food web was divided into 7 compartments, whose carbon biomasses and rates of exchange were determined from field data combined with inverse analysis, the latter being used to estimate missing rates. Results indicate that the system was characterized by high phytoplankton production and, in agreement with previous results, low bacterial production. Due to their high metabolism, metazoan zooplankton played a dominant role in the cycling of carbon. In contrast, the contribution of protozoa was small. The non-living particulate organic carbon compartment also played a key role, qualitatively and quantitatively, because detritus was directly consumed by all heterotrophic compartments.
\end{abstract}

KEY WORDS: Plankton · Food web - Inverse model analysis · Atoll lagoon C Coral reef F French Polynesia

\section{INTRODUCTION}

Typical coral reefs are generally considered to be dominated by benthic communities, with a very minor contribution by phytoplankton to primary production (Sargent \& Austin 1949, 1954, Odum \& Odum 1955, Sournia 1977, Kinsey 1985, Gattuso et al. 1993). This generalization does not apply, however, to atoll lagoons where, because of a relatively deep water column and scarcity of coral structures, the pelagic community plays a significant role. In atoll lagoons, the primary productivity of plankton exceeds that of benthos (e.g. Charpy-Roubaud 1988, Furnas 1988).

The first studies of planktonic food webs in coral reefs have shown that these are characterized by high abundance of zooplankton, which are a food source for corals (Russel 1934, Motoda 1938), high biomasses and metabolic rates of bacteria (Sargent \& Austin 1949, Odum \& Odum 1955, Sorokin 1973), and large stocks of detritus, which are mainly consumed by zooplankton (Marshall 1965, Gerber \& Marshall 1974). The biomasses and production rates of phytoplankton are

·E-mail: niquil@univ-perp.fr generally low, but highly variable (Sournia \& Ricard 1976, Lewis 1977, Sournia 1977, Kinsey 1985).

In French Polynesia, the benthic fauna of atoll lagoons is characterized by dominance of a few species, especlally filter-feeding bivalves (Salvat 1969). The pearl oyster Pinctada margaritifera was naturally the most abundant bivalve at the turn of the 20th century, but has since been heavily exploited for mother-of-pearl (Grand \& Hauti 1993). Overexploitation led to the near disappearance of this species, after which farming developed to produce black pearls. Because farmers suspend oysters on ropes in the water column, they are moving these benthic bivalves into the pelagic environment. Knowledge of the trophic functioning of the pelagic food web is thus essential to determining the standing stock of pearl oysters that can be supported by a given lagoon.

In the Tuamotu Archipelago, research on lagoon ecology started in 1974 as part of the Man and Biosphere UNESCO programme (Salvat 1976, 1988). Studies were concentrated on the lagoon of Takapoto Atoll, where pearl oyster farming was then being developed. Since 1990, studies on pearl oysters have been conducted within the framework of the Programme 
Général de Recherche sur la Nacre (hereinafter abbreviated as PGRN), the main objective of which is to assess the carrying capacity of the lagoon for oyster farming. Because of this suite of studies, Takapoto Atoll is one of the most investigated atolls in the world. Results of previous work (Charpy et al. 1992, 1994a, b, 1997. Charpy 1996, Torréton et al. 1997) do not provide, however, a complete description of the planktonic food web, because several flows between trophic compartments could not be quantified in the field.

Biological oceanographers are often confronted with the problem of deriving the whole picture of a food web from an incomplete data set. In order to do so, Vézina \& Platt (1988) applied the analytical method known as inverse analysis to planktonic food webs. Their inverse approach is an optimization technique which provides a complete steady-state model of the food web by estimating the unknown flows, using a parsimony principle and ancillary information to constrain the biological processes. Subsequent applications of inverse analysis to marine food webs have included euphotic-zone planktonic systems (Vézina \& Platt 1988, Ducklow et al. 1989, Vézina 1989, Jackson \& Eldridge 1992) and benthic systems (Eldridge \& Jackson 1992, 1993, Chardy et al. 1993) in temperate environments.

The present study applies inverse analysis to the PGRN data, with the purpose of obtaining a biologically realistic description of the whole planktonic food web in the lagoon of Takapoto Atoll. The resulting model is used to characterize the main features of the cycling of carbon in the lagoon.

\section{MATERIAL AND METHODS}

Study site. Takapoto Atoll $\left(145^{\circ} 10^{\prime} \mathrm{W}, 14^{\circ} 40^{\prime} \mathrm{S}\right)$ (Fig. 1) is located in the northwestern part of the 75 atoll Tuamotu Archipelago. The Iagoon has a surface area of $81 \mathrm{~km}^{2}$ (Andrefouet 1994) and a mean depth of $23 \mathrm{~m}$ (Ricard et al. 1979). It is isolated from the ocean by an almost continuous reef rim. A few shallow channels (less than $50 \mathrm{~cm}$ depth) sporadically allow water from the ocean to enter the lagoon, but currents in these are generally weak (Sournia \& Ricard 1976). The main means for water to leave the lagoon is by evaporation, which exceeds precipitation by an average of $50 \mathrm{~cm}$ per year (Rougerie 1979). The excess salts leave through the rim of the atoll by percolation (Rougerie $1979,1995)$. The renewal time of water is $2.5 \mathrm{yr}$ for $50 \%$ renewal and 18 yr for $99 \%$ (Magnier \& Wauthy 1976). Because tides and swell are negligible inside the lagoon, wind is the factor that determines water motion, with trade-winds from the east providing the dominant forcing (Rougerie 1979).

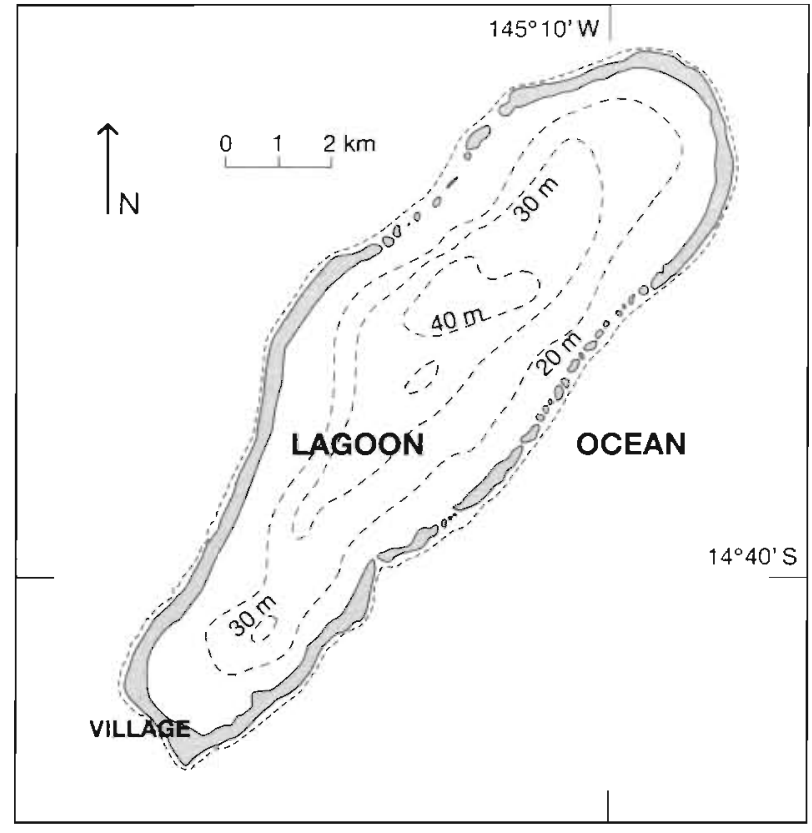

Fig. 1. Takapoto Atoll, Tuamotu Archipelago, French Polynesia

A village is located at the south end of the rim. The main economic activity on the atoll is pearl-oyster farming, which began in 1969, developed in the 1970 s (Salvat \& Richard 1985), and has flourished since the 1980s (Grand \& Hauti 1993).

Model development. A complete steady-state model of carbon cycling in the planktonic food web of Takapoto Atoll was built using PGRN data. The numerical method was the inverse approach developed by Vézina \& Platt (1988).

Data: The data used for constructing the food-web model (Table 1) result from studies conducted during the first part of the PGRN (1990 to 1994). We distributed the water-column biogenic carbon among 7 compartments. These compartments, which structure the ecosystem on the basis of processes and/or sizes, are: phytoplankton (autotrophic prokaryotes and eukaryotes), bacteria, protozoa (zooplankton $<35 \mu \mathrm{m}$ ), microzooplankton (from 35 to $200 \mu \mathrm{m}$ ), mesozooplankton (>200 $\mu \mathrm{m}$ ), detritus (non-living particulate organic carbon, POC, $>0.7 \mu \mathrm{m})$, and dissolved organic carbon, DOC $(<0.7 \mu m)$. Published values were transformed in order to obtain average flows expressed as $\mathrm{mg} \mathrm{C} \mathrm{m}^{-2}$ $\mathrm{d}^{-1}$ and stocks as $\mathrm{mg} \mathrm{C} \mathrm{m}^{-2}$.

Methods used to collect the data have been described in published papers and/or reports. They are briefly summarized here. Phytoplankton biomass and production were determined daily between 4 and 11 June 1991 ( 3 sites, 5 sampling depths). Chlorophyll a concentration was determined fluorometrically after fractionated filtration on $3 \mu \mathrm{m}$ and $1 \mu \mathrm{m}$ Nuclepore filters and Whatman GF/F filter. The carbon/ch]oro- 
Table 1. Field data and values used for the inverse analysis. Vertical water-column integration was over a mean depth of $23 \mathrm{~m}$ (Ricard et al. 1979)

\begin{tabular}{|c|c|c|c|}
\hline Description & Value in the model & Published value & Source \\
\hline Stocks & $\mathrm{mg} \mathrm{C} \mathrm{m} \mathrm{m}^{-2}$ & & \\
\hline Phytoplankton & 585 & $0.31 \pm 0.01 \mu g \mathrm{chl} \mathrm{al^{-1 }}{ }_{i} \mathrm{C} / \mathrm{chl}=82$ & Charpy et al. (1992) \\
\hline Bacteria & 300 & $13 \pm 2 \mu \mathrm{gCl} \mathrm{I}^{-1}$ & Torréton et al. (1997) \\
\hline Protozoa & 3 & $3 \mathrm{mg} \mathrm{C} \mathrm{m}^{-2}$ & Charpy et al. (1994a) \\
\hline Microzooplankton & 98 & $98 \mathrm{mg} \mathrm{C} \mathrm{m}^{-2}$ & Charpy et al. (1994a) \\
\hline Mesozooplankton & 47 & $47 \mathrm{mg} \mathrm{C} \mathrm{m}{ }^{-2}$ & Charpy et al. (1994a) \\
\hline Detritus & 2400 & $2400 \mathrm{mg} \mathrm{C} \mathrm{m}^{-2}$ & Charpy et al. (1994a) \\
\hline DOC & 33400 & $121 \pm 14 \mu \mathrm{M}$ & Torréton et al. (1997) \\
\hline Flows & $\mathrm{mgC} \mathrm{m}^{-2} \mathrm{~d}^{-1}$ & & \\
\hline Gross particulate primary prod. & 820 & $0.82 \pm 0.1 \mathrm{~g} \mathrm{C} \mathrm{m}^{-2} \mathrm{~d}^{-1}$ & Charpy et al. (1992) \\
\hline Bacterial prod. & 76 & $3.3 \pm 0.6 \mu \mathrm{gCl}^{-1} \mathrm{~d}^{-1}$ & Torréton et al. (1997) \\
\hline Microzooplankton prod. & 131 & $131 \mathrm{mg} \mathrm{C} \mathrm{m}^{-2} \mathrm{~d}^{-1}$ & Charpy et al. (1994a) \\
\hline Microzooplankton total ingestion & 342 & $342 \mathrm{mg} \mathrm{C} \mathrm{m} \mathrm{m}^{-2} \mathrm{~d}^{-1}$ & Charpy et al. (1994a) \\
\hline Microzooplankton respiration & 147 & $30.8 \mu \mathrm{mol} \mathrm{O} \mathrm{mg}^{-1} \mathrm{~d}^{-1}$ & Charpy et al. (1994b) \\
\hline Mesozooplankton prod. & 75 & $75 \mathrm{mgC} \mathrm{m}^{-2} \mathrm{~d}^{-1}$ & Charpy et al. (1994a) \\
\hline Mesozooplankton total ingestion & 358 & $358 \mathrm{mg} \mathrm{C} \mathrm{m}^{-2} \mathrm{~d}^{-1}$ & Charpy et al. (1994a) \\
\hline Mesozooplankton respiration & 147 & $63.5 \mu \mathrm{mol} \mathrm{O} 2 \mathrm{mg}^{-1} \mathrm{~d}^{-1}$ & Charpy et al. (1994b) \\
\hline
\end{tabular}

phyll a ratio was determined for Synechococcus and applied to total chlorophyll a since Synechococcus represented $67 \%$ of the pigment biomass (Charpy et al. 1992). Primary production was estimated from $4 \mathrm{~h}{ }^{14} \mathrm{C}$ in situ incubations (Charpy et al. 1992). We assumed that values corresponded to gross particulate primary production, given the short incubation time.

Bacteria and DOC (Torréton et al. 1997) were determined between 16 and 25 January 1994 (2 sites, subsurface sampling). DOC was the organic carbon passing through a Whatman GF/F filter. Bacteria were collected on $0.2 \mu \mathrm{m}$ Nuclepore filters, stained with DAPI, and counted under an epifluorescence microscope. Bacterial production was estimated by [methyl${ }^{3} \mathrm{H}$ ] thymidine incorporation into DNA.

The masses of detritus and zooplankton were determined monthly between June 1991 and December 1992. Total organic carbon was determined by $\mathrm{CHN}$ analysis after filtration on precombusted Whatman GF/F filters (Charpy et al. 1994a). ATP was used to estimate the living carbon in the size classes $0.7-1$, $1-3$, and $>3 \mu \mathrm{m}$. The mass of detritus was computed as the difference between total organic carbon $>0.7 \mu \mathrm{m}$ and the living organic carbon $>0.7 \mu \mathrm{m}$. Stocks of micro- and mesozooplankton were estimated from the dry weights of vertical net haul samples. The dry weights were transformed into carbon using a relationship determined for Tikehau Atoll (Charpy et al. $1994 a$, b). Protozoa were estimated by subtracting the carbon calculated for phytoplankton $>3 \mu \mathrm{m}$ from the living carbon in the class 3-35 $\mathrm{m}$ (Charpy et al. 1994a).

Metabolic rates for micro- and mesozooplankton were estimated in February 1994 from an overnight in situ incubation (Charpy et al. 1994b). Production rates were computed using the $\mathrm{C} / \mathrm{N} / \mathrm{P}$ ratios method
(Le Borgne et al. 1989). The respiration rates of microand mesozooplankton were calculated using a respiratory quotient of 1 , since it is likely that zooplankton mostly used carbohydrates for their metabolism. (R. Le Borgne pers. comm.).

A priori compartment model: The a priori model is the diagram of all flows likely to exist that must be estimated. We chose to consider flows of carbon only, and not of nitrogen, for reasons discussed later. Interactions with the lagoon bottom were combined into a single flow which included detritus sinking and resuspension. Other interactions with the bottom were not explicitly considered.

Several assumptions were made when constructing the model: both prokaryotic and eukaryotic phytoplankton can be grazed by zooplankton of any size class; bacteria are consumed only by protozoa, since most microzooplankton cannot efficiently graze bacterial-sized particles (Sherr \& Sherr 1984, Rassoulzadegan \& Sheldon 1986, Ducklow 1990); zooplankton feed on zooplankton compartments whose sizes are smaller than their own; detritus can be consumed by zooplankton of all size classes; protozoa can assimilate DOC (as shown for high molecular weight compounds by Sherr 1988 and Sherr \& Sherr 1988). Each living compartment can contribute to the detritus and DOC pools. Detritus are transformed into DOC by direct dissolution (mechanical fragmentation) and dissolution mediated by microbial activity (Morrissey 1985, Alongi 1988). The resulting model contained 32 flows (Table 2). The system has only 1 carbon input, i.e. gross phytoplankton production, and 3 outputs, i.e. respiration by all living compartments, detritus sinking, and production exported by mesozooplankton to higher trophic levels.

Inverse analysis: The inverse approach used here is a tool for constructing a complete model of flows 
Table 2. Flows in the a priori model (flow names are used in Fig. 3). For each flow, the value obtained from the inverse analysis and the corresponding resolution are given. Resolution values $>0.5$ are in bold

\begin{tabular}{|c|c|c|c|}
\hline Description & Flow name & $\begin{array}{l}\text { Inferred value } \\
\left(m g \mathrm{C} \mathrm{m}^{-2} \mathrm{~d}^{-1}\right)\end{array}$ & Resolution \\
\hline Gross phytoplankton production & gpp $\rightarrow$ phy & 863 & 0.589 \\
\hline Phytoplankton respiration & phy $\rightarrow$ res & 250 & 0.392 \\
\hline $\begin{array}{l}\text { Grazing of phytoplankton } \\
\text { by protozoa }\end{array}$ & phy $\rightarrow$ pro & 88 & 0.289 \\
\hline $\begin{array}{l}\text { Grazing of phytoplankton } \\
\text { by microzooplankton }\end{array}$ & phy $\rightarrow$ mic & 205 & 0.442 \\
\hline $\begin{array}{l}\text { Grazing of phytoplankton } \\
\text { by mesozooplankton }\end{array}$ & phy $\rightarrow$ mes & 167 & 0.442 \\
\hline DOC exudation by phytoplankton & phy $\rightarrow$ doc & 43 & 0.589 \\
\hline Phytoplankton detritus production & phy $\rightarrow$ det & 109 & 0.289 \\
\hline Protozoa respiration & pro $\rightarrow$ res & 51 & 0.316 \\
\hline $\begin{array}{l}\text { Grazing of protozoa } \\
\text { by microzooplankton }\end{array}$ & pro $\rightarrow$ mic & 40 & 0.405 \\
\hline $\begin{array}{l}\text { Grazing of protozoa } \\
\text { by mesozooplankton }\end{array}$ & pro $\rightarrow$ mes & 1.5 & 0.405 \\
\hline Protozoa egestion & pro $\rightarrow$ det & 12 & 0.176 \\
\hline DOC excretion by protozoa & pro $\rightarrow$ doc & 17 & 0.252 \\
\hline Microzooplankton respiration & mic $\rightarrow$ res & 147 & 1.000 \\
\hline $\begin{array}{l}\text { Grazing of microzooplankton } \\
\text { by mesozooplankton }\end{array}$ & mic $\rightarrow$ mes & 131 & 1.000 \\
\hline Microzooplankton egestion & mic $\rightarrow$ det & 46 & 0.563 \\
\hline $\begin{array}{l}\text { DOC excretion by } \\
\text { microzooplankton }\end{array}$ & $\mathrm{mic} \rightarrow \mathrm{doc}$ & 18 & 0.563 \\
\hline Mesozooplankton respiration & mes $\rightarrow$ res & 147 & 1.000 \\
\hline Mesozooplankton egestion & mes $\rightarrow$ det & 82 & 0.563 \\
\hline $\begin{array}{l}\text { DOC excretion by } \\
\text { mesozooplankton }\end{array}$ & mes $\rightarrow$ doc & 54 & 0.563 \\
\hline Bacterial respiration & bac $\rightarrow$ res & 51 & 0.492 \\
\hline Use of bacteria by protozoa & bac $\rightarrow$ pro & 28 & 0.412 \\
\hline Bacteria detritus production & bac $\rightarrow$ det & 48 & 0.353 \\
\hline DOC excretion by bacteria & $\mathrm{bac} \rightarrow \mathrm{doc}$ & 0 & 0.373 \\
\hline Grazing of detritus by protozoa & det $\rightarrow$ pro & 0 & 0.176 \\
\hline $\begin{array}{l}\text { Grazing of detritus } \\
\text { by microzooplankton }\end{array}$ & $\operatorname{det} \rightarrow$ mic & 97 & 0.405 \\
\hline $\begin{array}{l}\text { Grazing of detritus } \\
\text { by mesozooplankton }\end{array}$ & $\operatorname{det} \rightarrow$ mes & 58 & 0.405 \\
\hline Use of detritus by bacteria & $\operatorname{det} \rightarrow$ bac & 0 & 0.353 \\
\hline Detritus dissolution to DOC & $\operatorname{det} \rightarrow$ doc & 0 & 0.252 \\
\hline DOC consumption by bacteria & $\mathrm{doc} \rightarrow \mathrm{bac}$ & 127 & 0.373 \\
\hline DOC consumption by protozoa & doc $\rightarrow$ pro & 6.4 & 0.252 \\
\hline Sinking of detritus & det $\rightarrow$ los & 142 & 0.316 \\
\hline $\begin{array}{l}\text { Grazing of mesozooplankton } \\
\text { by higher level organisms }\end{array}$ & mes $\rightarrow \operatorname{los}$ & 75 & 1.000 \\
\hline
\end{tabular}

Table 3. Equations used as complements to the mass balance equations, to take into account field estimates. Modified from Vézina \& Platt (1988)

\begin{tabular}{|ll|}
\hline Input data & Corresponding equation \\
\hline Gross particulate primary production & $(\mathrm{gpp} \rightarrow \mathrm{phy})-(\mathrm{phy} \rightarrow \mathrm{doc})$ \\
Bacterial production & $(\mathrm{bac} \rightarrow \mathrm{pro})+(\mathrm{bac} \rightarrow \mathrm{det})$ \\
Microzooplankton production & mic $\rightarrow$ mes \\
Microzooplankton respiration & mic $\rightarrow$ res \\
Microzooplankton & $(\mathrm{phy} \rightarrow \mathrm{mic})+(\mathrm{pro} \rightarrow \mathrm{mic})+$ \\
total ingestion & $(\mathrm{bac} \rightarrow \mathrm{mic})+(\mathrm{det} \rightarrow \mathrm{mic})$ \\
Mesozooplankton production & mes $\rightarrow$ los \\
Mesozooplankton respiration & mes $\rightarrow$ res \\
Mesozooplankton & (phy $\rightarrow$ mes $)+($ pro $\rightarrow$ mes $)+$ \\
total ingestion & (mic $\rightarrow$ mes $)+($ det $\rightarrow$ mes $)$ \\
\hline
\end{tabular}

among compartments. The resulting model is static (i.e. without temporal variations). Hence, the purpose of such a model is not prediction but the characterization of the food web. The approach is based on the steady-state assumption that each compartment has a constant mass, i.e. that the total flows entering any compartment are equal to the total output flows. The balance between in- and outflows leads to a mass-balanced equation for each compartent, resulting in 7 equations describing the 7 compartments. In addition, the PGRN data provided 8 equations (Table 3). As there are only 15 equations for 32 unknowns, the system is mathematically underdetermined with an infinity of solutions.

Vézina \& Platt (1988) applied 2 additional criteria to obtain a single solution. The first is a set of constraints, expressed in terms of flows, that provide limits to the rates and efficiencies of biological processes. For example, the efficiency of ingestion by zooplankton was required to be less than an unrealistically high level when compared to literature data. This can be expressed as an inequality, called hereafter a 'biological constraint'. Applying such constraints reduce the domain of solutions but still allows an infinity of possible solutions for the set of flows. The second criterion is based on a parsimony principle. It assumes that the 'best' set of flows is that with the smallest Euclidean norm (sum of squares) (Vézina 1989). These 2 additional criteria lead to a single solution vector, which describes the flows between compartments of the system, or between one compartment and the outside of the system. The algorithmic technique is given in Vézina \& Platt (1988) and Vézina (1989).

We used constraints (Table 4) similar to those of Vézina \& Platt (1988), with the exception of ingestion by microzooplankton and mesozooplankton which were not constrained here because they were fully determined by the available field data. Moreover, we did not constrain minimum microzooplankton excretion because the value in 
Vézina \& Platt conflicted with field determinations of microzooplankton metabolism in Takapoto Atoll. The resulting constraints comprised 26 inequalities (Table 4 ). The fact that each of the 32 flows must be non-negative resulted in 32 additional relationships, yielding a total of 58 inequalities.

Model analysis. Descriptive indices: We calculated an index of recycling $(L)$ as the sum of all internal flows (flows between 2 compartments) divided by the net $\mathrm{C}$ flow entering the system (gross primary production minus phytoplankton respiration). This index provides a measure of the number of times an atom of carbon is transformed on its way through the system before it exits (Jackson \& Eldridge 1992). L $\geq 1$ because each carbon atom is counted at least once before leaving the system.

We also computed other indices to characterize the relative importance of each living compartment. $F_{\text {bac }}$ is the fraction of bacterial production relative to phytoplankton production; $F_{\text {pror }} F_{\text {mic }}$ and $F_{\text {mes }}$ are the fractions of carbon going through the protozoa, microzooplankton, and mesozooplankton compartments, respectively, relative to the sum of flows through all 3 zooplankton compartments.

Resolution of each flow: The resolution of a flow quantifies how much that flow is constrained by the 15 equations (mass balance equations plus equations corresponding to field data). The resolution, whose calculation is described in Vézina (1989), has a value between 0 and 1 . Flows with a resolution of 1 are fully determined by the equations and therefore do not change after applying the biological constraints. The lower the resolution, the stronger the effect of the biological constraints on the flow (Vézina 1989). Hence, the resolution quantifies the sensitivity of each estimated flow value to the assumed food web structure and the field input data (Vézina \& Platt 1988).

Sensitivity analyses: In order to test its robustness, the model was subjected to 3 sensitivity analyses. The first two assessed the significance of each input variable to the resulting solution. The third one calculated the sensitivity of the result to the pattern of flows, i.e. the choices of flows made when building the a priori model.

Firstly, the sensitivity of calculated flows to each input variable was determined by calculating new solutions of the model after changing the input value of the variable by $\pm 10 \%$. Secondly, more drastic changes to the available field data were considered. On the one hand, flow values in field data were removed and new solutions of the model were calculated; on the other hand, the input value for primary production was divided by 2 , which provided a rate close to that published by Sournia \& Ricard (1976). Thirdly, the structure of the model was modified, i.e. problematic flows were added to and/or removed from the a priori model: ingestion of DOC by protozoa (removed), consumption of bacteria by microzooplankton and mesozooplankton (added), and a combination of the 2 changes.

Table 4. List of minimum and maximum values used as biological constraints (Vézina \& Platt 1988). $T$ is the mean annual water temperature, which is $28^{\circ} \mathrm{C}$ in the lagoon of Takapoto Atoll (Charpy et al. 1994a). The lower and upper bounds are expressed as inequalities involving the concerned flow, sum of flows, or rate

\begin{tabular}{|lll|}
\hline List of biological constraints & Lower bound & Upper bound \\
\hline Respiration & & \\
Phytoplankton & $5 \%$ of gross primary production & $30 \%$ of gross primary production \\
Protozoa & $6.4 \%$ of biomass $\times$ exp $(0.0693 T)$ & None \\
Microzooplankton & $7.2 \%$ of biomass $\times$ exp $(0.0693 T)$ & None \\
Mesozooplankton & $2.3 \%$ of biomass $\times$ exp $(0.0693 T)$ & None \\
Excretion & $5 \%$ of gross primary production & $50 \%$ of gross primary production \\
Phytoplankton & $33 \%$ of respiration & $100 \%$ of respiration \\
Protozoa & None & $100 \%$ of respiration \\
Microzooplankton & $33 \%$ of respiration & $100 \%$ of respiration \\
Mesozooplankton & & \\
Assimilation efficiency & $50 \%$ & $90 \%$ \\
Protozoa & $50 \%$ & $90 \%$ \\
Microzooplankton & $50 \%$ & $90 \%$ \\
Mesozooplankton & & $60 \%$ \\
Net production efíiciency & $10 \%$ & $60 \%$ \\
Bacteria & $10 \%$ & $60 \%$ \\
Gross production efficiency & $10 \%$ & $40 \%$ \\
Protozoa & None & $546 \%$ of biomass $\times$ exp $(0.0693 T)$ \\
Microzooplankton & None & \\
Mesozooplankton & & \\
Ingestion & & \\
Protozoa & &
\end{tabular}




\section{RESULTS}

\section{Description of the inferred carbon cycle}

The field data (Table 1) were spatially and temporally averaged over the lagoon, using a vertical integration depth of $23 \mathrm{~m}$. The values for carbon flows, resulting from the inverse analysis, are therefore similarly averaged values (numerical values in Table 2, graphical representation in Fig. 2).

The input of carbon ( $863 \mathrm{mg} \mathrm{C} \mathrm{m} \mathrm{m}^{-2} \mathrm{~d}^{-1}$ ) is the sum of the field-determined gross particulate primary production ( $820 \mathrm{mg} \mathrm{C} \mathrm{m}^{-2} \mathrm{~d}^{-1}$ ) and DOC exudation calculated by the model, which is $5 \%$ of the total input (this value corresponds to the lower bound of the constraint in Vézina \& Platt 1988). The computed respiration by phytoplankton ( $29 \%$ of the gross primary production) is close to the upper limit allowed by the corresponding constraint.

Mesozooplankton have the largest total inflow of all consumer compartments. This value results from the high ingestion rate of total POC estimated by Charpy et al. (1994b), i.e. $358 \mathrm{mg} \mathrm{C} \mathrm{m}{ }^{-2} \mathrm{~d}^{-1}$. The value of $F_{\text {mes }}$ indicates that the flows toward mesozooplankton are $43 \%$ of the total for all zooplankton, which is higher than their fraction of the total zooplankton biomass (32\%).

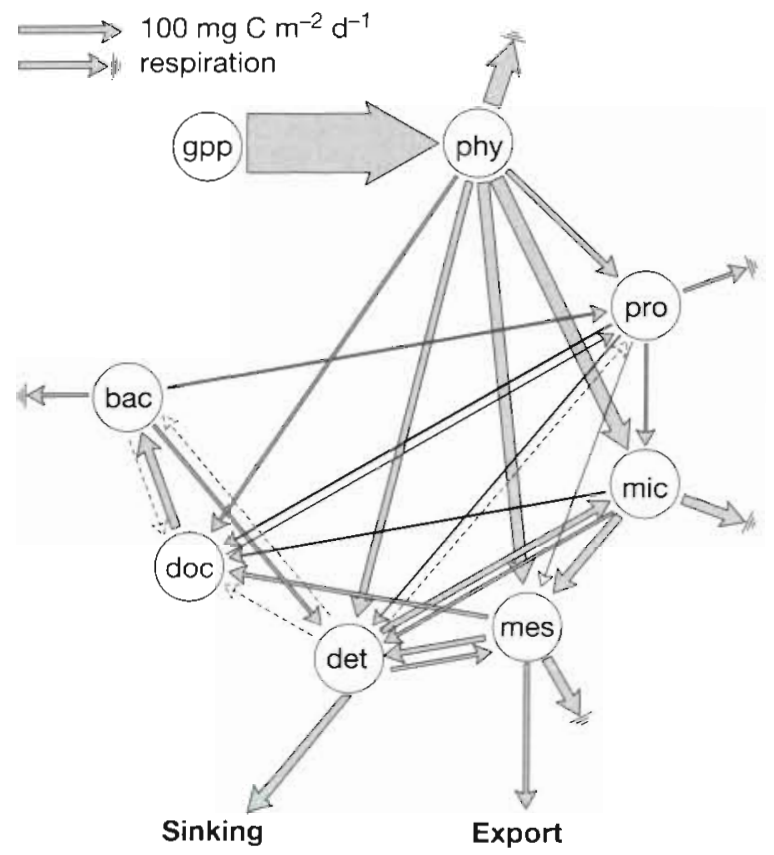

Fig. 2. Inverse solution for planktonic food-web flows in the lagoon of Takapoto Atoll. Each carbon flow is represented by an arrow whose width is proportional to the calculated value. Dotted arrows: flows present in the a priori model, whose computed values are null. gpp = gross primary production, phy = phytoplankton, pro $=$ protozoa, mic $=$ microzooplank ton, mes = mesozooplankton, det = detritus, doc = dissolved organic carbon, bac $=$ bacteria
Mesozooplankton grazing is mainly on phytoplankton $(47 \%)$ and microzooplankton (37\%). Respiration and grazing mortality are the largest non-phytoplankton fluxes out of the system ( $25 \%$ of the overall output).

The total carbon flow through microzooplankton is almost as large as the flow through mesozooplankton, with an ingestion of $342 \mathrm{mg} \mathrm{C} \mathrm{m} \mathrm{m}^{-2} \mathrm{~d}^{-\mathrm{t}}$ and $F_{\mathrm{mc}}=42 \%$. The microzooplankton compartment has the largest biomass among all zooplankton ( $66 \%$ of the total). Most of the input flow (60\%) results from the grazing on phytoplankton, although grazing on detritus also provides a substantial fraction of the carbon (28\%). Grazing on protozoa is small (12\%).

The total ingestion by protozoa estimated by inverse analysis is $122 \mathrm{mg} \mathrm{C} \mathrm{m} \mathrm{m}^{-2} \mathrm{~d}^{-1}$, which is the maximum value allowed by the biological constraint. $F_{\text {pro }}=15 \%$ is the lowest value among all zooplankton compartments, but it is high compared to the protozoa biomass which is only $2 \%$ of the total zooplankton biomass.

The carbon flow through bacteria is almost the same as that through protozoa, $127 \mathrm{mg} \mathrm{C} \mathrm{m}{ }^{-2} \mathrm{~d}^{-1}$. The value $F_{\text {bac }}=15 \%$ indicates that bacterial production is small compared to gross primary production. Carbon is lost by bacteria through respiration (40\%), formation of detritus $(38 \%)$, and consumption by protozoa $(22 \%)$.

The flow through detritus, $297 \mathrm{mg} \mathrm{C} \mathrm{m} \mathrm{m} \mathrm{d}^{-1}$, is large relative to that through the bacteria and protozoa compartments. This carbon is either consumed by grazers or lost through sinking (estimated to be $142 \mathrm{mg} \mathrm{C}$ $\mathrm{m}^{-2} \mathrm{~d}^{-1}$ ). The dissolution of detritus into DOC, either directly or mediated by bacteria, was included in the a priori model but estimated to be null by the inverse analysis.

\section{Analysis of the food web}

The recycling index calculated from the results of the inverse analysis is $L=2.25$. This means that the sum of all flows through all compartments other than phytoplankton is 2.25 times the carbon that entered the system once it passed through the phytoplankton compartment.

The resolutions of flows vary from 0.18 to 1 (Table 2). The 4 flows with resolutions of 1 (i.e. fully determined by the field data combined with the mass balance equations) all involved micro- or mesozooplankton. The flows with resolutions $>0.5$ are mostly those involving phytoplankton and micro- and mesozooplankton. The lowest resolutions $(0.18$ to 0.25$)$ concern flows from the protozoa, detritus, and DOC compartments, as their masses provided the only available information that could be used in the analysis.

The first sensitivity analysis (Fig. 3) shows that gross primary production and the ingestion rates of micro- 


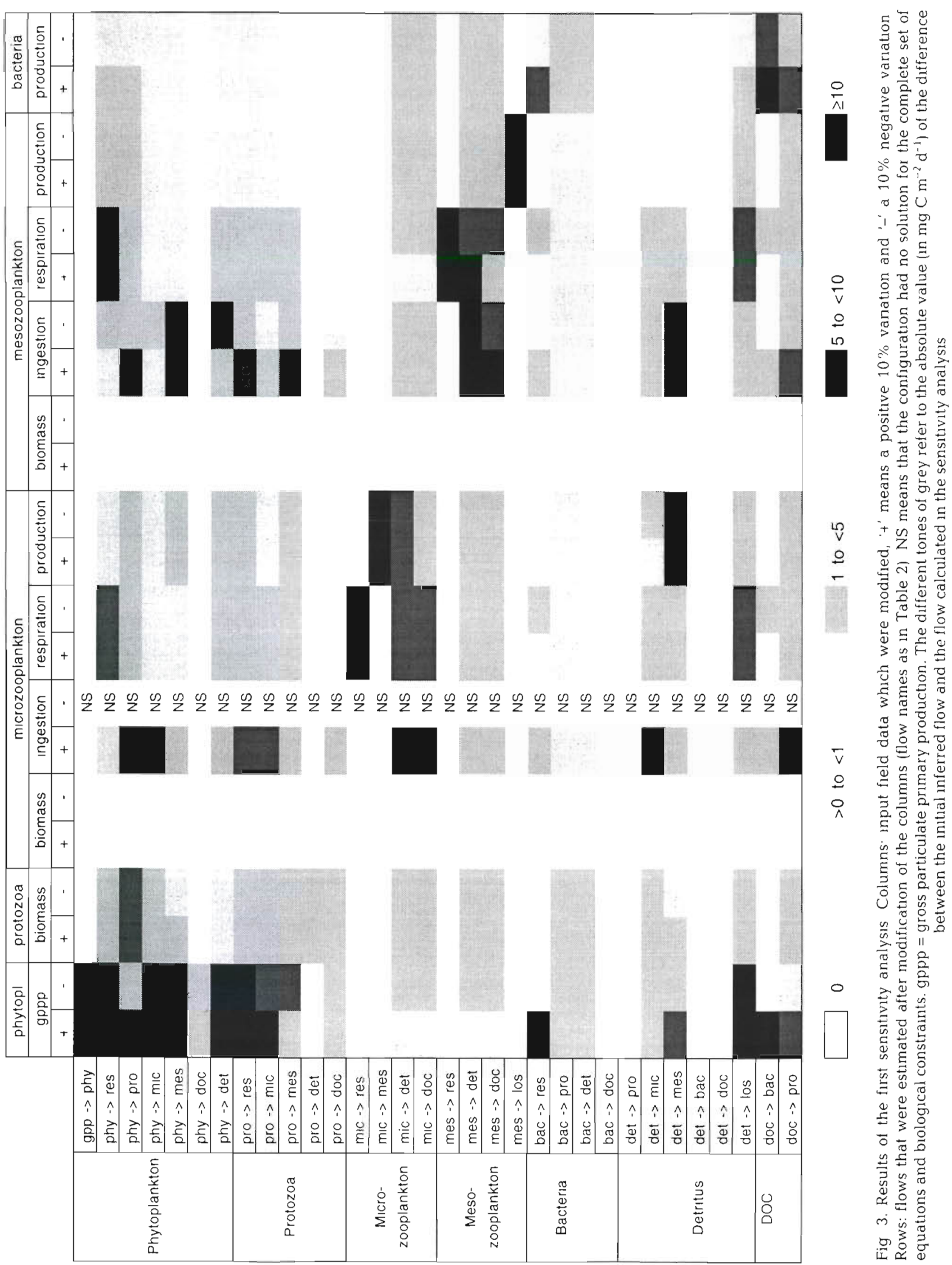


and mesozooplankton strongly affected the flows from or to other compartments, i.e. mainly protozoa and DOC. In contrast, the biomass of zooplankton, except for protozoa, had no influence on flows. There was a positive link between bacterial production and the flows from the DOC compartment.

The second sensitivity analysis (Table 5) shows that, even when drastic changes were applied, the general structure of the model did not change much. The removal of data on the metabolism of either micro- or mesozooplankton resulted in a decrease of the total flow through the corresponding compartment. Even when the 6 metabolic values (i.e. ingestion, respiration and production, for micro- and mesozooplankton) were removed, there still was a dominance of mesozooplankton (46\%) over microzooplankton (32\%) and protozoa $(22 \%)$. The latter change resulted, however, in a decrease of the recycling index, $L$, from 2.25 to 1.72. This is because of a decrease in the required carbon passing through the 3 zooplankton compartments relative to the initial (PGRN) model. Similarly, there was a decrease in recycling when bacterial production was removed, because of a small decrease in the total carbon passing through the bacteria and DOC compartments, the latter being the main source of carbon for bacteria. When primary production was divided by 2 , the recycling increased markedly. This is because, with half the carbon running through the model, recycling processes became essential for satisfying the demand of carbon from all compartments.

Table 6 . Results of the third sensitivity analysis, concerning the structure of the a priori model: total throughput through each compartment, and $F$ and $L$ indices. Three modifications were considered: flow from DOC to protozoa removed (I); flows from bacteria to microzooplankton and mesozooplankton allowed (II); and a combination of the previous 2 changes (III). $F$ and $L$ indices are defined in Table 5

\begin{tabular}{|lrrrr|}
\hline & PGRN & I & II & III \\
\hline Total throughput through: & & & \\
Phytoplankton & 863 & 863 & 863 & 863 \\
Protozoa & 122 & 122 & 122 & 122 \\
Microzooplankton & 342 & 342 & 342 & 342 \\
Mesozooplankton & 358 & 358 & 358 & 358 \\
Detritus & 297 & 299 & 286 & 285 \\
DOC & 133 & 143 & 119 & 126 \\
Bacteria & 127 & 127 & 135 & 144 \\
Indices & & & & \\
$F_{\text {bac }}(\%)$ & 15 & 15 & 16 & 17 \\
$F_{\text {pro }}(\%)$ & 15 & 15 & 15 & 15 \\
$F_{\text {mic }}(\%)$ & 42 & 42 & 42 & 42 \\
$F_{\text {mes }}(\%)$ & 43 & 43 & 43 & 43 \\
$L$ & 2.25 & 2.24 & 2.20 & 2.18 \\
& & & & \\
\hline
\end{tabular}

The third sensitivity analysis, which consisted in adding and/or removing flows, did not affect the main characteristics of the model (Table 6). The role of bacteria remained low, the overall distribution of carbon among the 3 zooplankton compartments was unchanged, and the recycling index varied little.

\section{DISCUSSION}

Table 5. Results of the second sensitivity analysis. The total throughput through each compartment and the $F$ and $L$ indices are given for: the initial model (PGRN); cases with flows being removed in turn, i e ingestion by micro-or mesozooplankton ( $I_{M I C}$ and $I_{M E S}$, ingestion, respiration and production for microzooplankton (MIC), mesozooplankton (MES), and both micro- and mesozooplankton ( $\mathrm{ZOO})$, and bacterial production $\left(\mathrm{P}_{\mathrm{B}}\right)$; and primary production being divided by $2\left(\mathrm{P}_{\mathrm{p}} / 2\right)$. $F_{\mathrm{bdr}}$ : fraction $(\%)$ of bacterial production relative to phytoplankton production. $F_{\text {pro, }}, F_{\text {mic }}, F_{\text {mes }}$ : fraction (\%) of carbon through protozoa, microzooplankton and mesozooplankton, respectively, relative to the sum of the three. $L$ : recycling index

\begin{tabular}{|lcccccccc|}
\hline & PGRN & $\mathrm{I}_{\text {MIC }}$ & $\mathrm{I}_{\text {MES }}$ & MIC & MES & ZOO & $P_{B}$ & $P_{\mathrm{p}} / 2$ \\
\hline \multicolumn{2}{l}{ Total throughput through: } & & & & & & & \\
Phytoplankton & 863 & 863 & 863 & 863 & 863 & 863 & 863 & 432 \\
Protozoa & 122 & 122 & 122 & 122 & 122 & 122 & 122 & 122 \\
Microzooplankton & 342 & 309 & 342 & 180 & 342 & 171 & 342 & 342 \\
Mesozooplankton & 358 & 358 & 301 & 358 & 280 & 249 & 358 & 358 \\
Detritus & 297 & 275 & 255 & 269 & 245 & 242 & 286 & 214 \\
DOC & 133 & 127 & 128 & 127 & 127 & 127 & 110 & 148 \\
Bacteria & 127 & 127 & 127 & 127 & 127 & 127 & 104 & 127 \\
Indices & & & & & & & & \\
$F_{\text {bac }}(\%)$ & 15 & 15 & 15 & 15 & 15 & 15 & 12 & 29 \\
$F_{\text {pro }}(\%)$ & 15 & 16 & 16 & 19 & 16 & 22 & 15 & 15 \\
$F_{\text {mic }}(\%)$ & 42 & 39 & 45 & 27 & 46 & 32 & 42 & 42 \\
$F_{\text {mes }}(\%)$ & 43 & 45 & 39 & 54 & 38 & 46 & 43 & 43 \\
$L$ & 2.25 & 2.15 & 2.09 & 1.96 & 2.05 & 1.72 & 2.11 & 3.24 \\
& & & & & & & & \\
\hline
\end{tabular}

\section{Food-web characteristics inferred from the model}

The major pathways of carbon in the pelagic food web are through microand mesozooplankton, not protozoa (i.e. 15,42 , and $43 \%$ through protozoa, microzooplankton, and mesozooplankton, respectively). The protozoan biomass in Takapoto Atoll (3 $\mathrm{mg} \mathrm{C} \mathrm{m}^{-2}$ ) might have been underestimated, since it is much lower than the biomass in the lagoon of nearby Tikehau Atoll (60 $\mathrm{mg} \mathrm{C} \mathrm{m} \mathrm{m}^{-2}$; Charpy \& CharpyRoubaud 1990). However, increasing the protozoan biomass from 3 to 60 and $120 \mathrm{mg} \mathrm{C} \mathrm{m}^{-2}$ did not significantly change the respective contributions of the various zooplankton size classes to the carbon flows, and it increased the flow through protozod to only $24 \%$ for both biomass values (the flow values for the 2 higher protozoan biomasses 
are the same because the biomass is only used to set the biological constraints). The low contribution of protozoa is therefore a robust characteristic of the trophic structure.

In British waters, Vézina \& Platt (1988) found an increasing carbon flow with increasing size of zooplankton, i.e. 15,49 , and $36 \%$ in the English Channel and 19 , 27 , and $53 \%$ in the Celtic Sea for protozoa, microzooplankton, and mesozooplankton, respectively. In contrast, Jackson \& Eldridge (1992) observed a decreasing carbon flow $(40,47$, and $13 \%)$ in the California Basin for the same 3 zooplankton compartments. The latter corresponds to a food chain where mesozooplankton fed on microzooplankton which, in turn, fed on protozoa. Our results and those of Vézina \& Platt (1988) appear to be exceptions to the latter 'classical' scheme, which reflect preferential herbivory for all size classes of zooplankton.

The fact that zooplankton $>35 \mu \mathrm{m}$ dominated the carbon cycle seems inconsistent with the observed high abundance of picophytoplankton and their high contribution to primary production (Blanchot et al. 1989. Charpy et al. 1992). In Takapoto Atoll, the production of cyanobacteria accounts for $60 \%$ of the total phytoplankton production (Charpy et al. 1992), whereas the consumption of phytoplankton by protozoa represents only $19 \%$ of the phytoplankton which is directly eaten by zooplankton. It follows that part of the picophytoplankton is grazed by micro- or mesozooplankton. This is not unrealistic given that small particles are efficiently ingested by the appendicularian Oikopleura fusiformis (Fenaux 1989), which is among the 8 most abundant holoplankton taxa in the zooplankton community of Takapoto Atoll (Renon 1989)

Bacteria are the other living group consumed by protozoa. Most of them are free-living, small-sized cells (Ducklow 1990, J.-P. Torréton pers. comm.) that are believed to be mostly grazed by protozoa. This compartment is characterized by low production $76 \mathrm{mg} \mathrm{C}$ $\mathrm{m}^{-2} \mathrm{~d}^{-1}$ ), despite its high biomass (300 $\left.\mathrm{mg} \mathrm{C} \mathrm{m}^{-2}\right)$. Since a similar result was obtained for Tikehau Atoll, where the production and biomass of bacteria are $143 \mathrm{mg} \mathrm{C}$ $\mathrm{m}^{-2} \mathrm{~d}^{-1}$ and $1175 \mathrm{mg} \mathrm{C} \mathrm{m}^{-2}$, respectively (Torréton et al. 1997), a low production to biomass ratio seems to be a general characteristic of the bacterial community in Polynesian atoll lagoons. Bacteria process $15 \%$ of the carbon input, which is at the lower end of the range reviewed by Azam et al. (1983) for marine systems (10 to $50 \%)$. Hence, although they make up a high biomass, bacteria contribute little to the carbon cycle in the studied system. It must be kept in mind, however, that our model considers the water column only, which does not preclude high activity of benthic bacteria as shown on the Great Barrier Reef (Wilkinson 1987).
In contrast to protozoa and bacteria, the detritus compartment plays a significant role in the food web. Qualitatively, this compartment adds a high degree of complexity to the model because detritus can be consumed by all heterotrophic compartments; quantitatively, the total flow through this compartment is more than twice that through bacteria. Several zooplankters are known to graze detritus in reef waters, where this food source can account for up to $95 \%$ of their gut contents (Gerber \& Marshall 1974, Gerber \& Gerber 1979). Detritus consumption has been emphasized by Sorokin (1990) and Arias-González (1993) as a general characteristic of coral reef ecosystems.

The recycling index in Takapoto lagoon (2.25) is similar to values calculated from the results obtained by Vézina \& Platt (1988) in the English Channel (2.49) and the Celtic Sea (2.27), and by Jackson \& Eldridge (1992) in California waters (2.46). Hence, the efficiency of carbon recycling in pelagic systems does not seem to be very different in temperate and tropical ecosystems. Two benthic systems were investigated with the inverse approach. The 7-compartment benthic network of the Bay of Saint-Brieuc has $L=1.75$ (data from Chardy et al. 1993), which is consistent with the low efficiency of energy transfer stressed by the authors. In the 8-compartment benthic systems of Santa Monica Basin and Patton Escarpment (data from Eldridge \& Jackson 1993), the $L$ values are much higher, i.e. 2.79 and 3.00 respectively. The $L$ index, however, is sensitive to the number and the nature of compartments involved, so that direct comparison of benthic and pelagic systems may not be possible because these characteristics differ in the 2 types of systems.

The intermediate value of the recycling index for the planktonic system of Takapoto Atoll contrasts with previous results for typical coral reefs. These systems have very high efficiency in the use of primary energy sources by heterotrophic processes (Sorokin 1990), and high recycling which allows the maintenance of very high animal biomasses together with almost null excess production (Kinsey 1985, Crossland et al. 1991, Opitz 1993, Arias-González et al. 1997). As already mentioned at the beginning of the 'Introduction', atoll lagoons and typical coral reefs are very different systems.

The first sensitivity analysis shows that carbon cycling in the planktonic food web mainly depends on the input of carbon in the system, i.e. primary production. A $10 \%$ variation in this input strongly modified all the other flow values. The system is also strongly dependent on the metabolic rates of the metazoan compartments. Finally, the small value of the total flow through the DOC compartment is linked to the low bacterial production. A large reservoir of DOC that is little used by the planktonic system seems to be the 
rule in Polynesian atoll lagoons (e.g. Tikehau Atoll; Torréton \& Dufour 1996).

One of the aims of the present paper was to show that it is possible to derive a large number of characteristics of a planktonic system from an incomplete data set. A critical analysis of the data used to build the model is beyond the scope of the paper. One of the potential problems of the approach is that the data were collected at different sites and periods of the year, and averaged over space and time before assimilation in the analysis. The drastic sensitivity analyses which were applied to the model showed, however, that the observed patterns were resistant to changes in both the input data (first and second sensitivity analyses) and the structure of the model (third sensitivity analysis). The food-web characteristics derived from the inverse analysis are therefore robust.

Despite the above considerations, the very high values for the micro- and mesozooplankton flows deserve some discussion. The ratios of ingestion and production to biomass are, for microzooplankton, 349 and $134 \%$, respectively, and, for mesozooplankton 762 and $160 \%$. These values seem unusually high in comparison to mean allometric models (e.g. Moloney \& Field 1989). The high environmental temperature and the nature of the organisms present (especially the appendicularians), however, favor metabolic values higher than those of a 'mean' population (Le Borgne pers. comm.). Moreover, the values we used for production and ingestion are close to those observed in the lagoon of Uvea Atoll, New Caledonia (Le Borgne et al. 1997), where the ratio of mesozooplankton ingestion to biomass did not exceed $350 \%$. The extremely high value $(762 \%)$ of this ratio in the lagoon of Takapoto Atoll may have been caused by an underestimation of the mesozooplankton biomass. This, however, would have no consequence for our model since the first sensitivity analysis showed that the biomasses of micro- and mesozooplankton had no influence on the result.

\section{Methodological choices and consequences}

The inverse approach, as applied by Vézina \& Platt (1988), is based on the assumption that the model is at steady state. In other words, the masses of the different compartments are assumed to be constant. In Takapoto Atoll, the observed variations of phytoplankton and micro- and mesozooplankton biomasses from one day to another did not exceed, in general, half the biomasses of the previous day and occurred randomly in positive and negative directions (Charpy et al. 1994a, $b, 1997)$. Changes in flows needed to obtain such small changes in biomasses would be very low compared to our calculated flows. Similarly, there was no clear sea- sonal pattern of variation. At all times during the year, the pelagic ecosystem varied only a little around the mean state represented by the model.

Only carbon flows were considered in the present study, whereas both nitrogen and carbon have been considered in most previous uses of inverse analysis (e.g. Vézina \& Platt 1988, Eldridge \& Jackson 1992, 1993, Jackson \& Eldridge 1992). This is because no field data were available for Takapoto Atoll on the uptake of nitrogen by phytoplankton. Hence, a coupled carbon-nitrogen model would have been solely based on $\mathrm{C} / \mathrm{N}$ ratios from the literature, which would not have brought any additional information on the functioning of the system. Obtaining estimates of phytoplankton nitrogen uptake is difficult in coral reef environments, where extremely low values of dissolved $\mathrm{N}$ nutrients impede the use of the ${ }^{15} \mathrm{~N}$ technique. The same choice was also made by Vézina \& Pace (1994) in a study of planktonic food webs in lakes.

Our a priori model differed from that of Vézina \& Platt (1988) in that it included available information on coral reef ecosystems (Kinsey 1985, Alongi 1988, Sorokin 1990, Arias-González 1993) and recent advances concerning the microbial food web (Sherr \& Sherr 1984, Rassoulzadegan \& Sheldon 1986, Sherr 1988, Ducklow 1990). The major differences were the addition of 3 pathways: detritus grazed by zooplankton, detritus processed by microbial degradation, and consumption of DOC by protozoa. As a consequence, the food web is more complex in the present model than in previous ones, especially concerning the key role played by detritus and with protozoa being an obligatory link from bacteria to the large-sized consumers.

Choosing the constraints is a key step of inverse analysis. The constraints used in the present study were taken from Vézina \& Platt (1988), although these came from literature mainly dealing with temperate systems. We nevertheless assumed that the resulting relationships could be applied to a tropical system, since they concern physiological limits and most of them are functions of temperature.

Flows to and from the protozoa, detritus and DOC compartments have low resolution values, since no field data were available to estimate them. Because constraints were applied to the living compartments only, processes concerning the protozoa compartment were probably realistically defined, but this may not have been the case for the DOC and detritus compartments, which were allowed to vary freely. Similarly, no constraint could be applied to detrital sinking, which was based on field data in the models of Vézina \& Platt (1988). Sinking rates were not determined in Takapoto Atoll, but the value computed by the model $(6 \%$ of the detritus mass sinking every day) seems realistic since it 
is similar to the $8 \%$ flux determined in nearby Tikehau Atoll (Charpy \& Charpy-Roubaud 1990). In contrast. the inverse analysis calculated an unrealistic null value for the degradation of detritus, either direct or mediated by bacteria. The only way to obtain a more realistic estimate for these flow values would have been to add new constraints. Dissolution of detritus in coral reefs ecosystems is, however, poorly documented and, because it mainly depends on the chemical composition of detritus, the processes involved could not be extrapolated from temperate environments.

The model is finally determined by the parsimony principle, which is essential for the selection of a unique solution. Using this non-biological criterion is classical in biology. It was first stated by the English logician William Ockham (1290-1349) as: 'unnecessary assumptions should be avoided when formulating hypothesis'. This principle (also known as Ockham's razor) is often used in the construction of phylogenic trees, by considering that evolutionary changes are rare and that no changes have occurred other than those necessary to explain the presently observed differences (Darlu \& Tassi 1993). Applying the parsimony principle to a steady-state food-web model implies that: (1) the carbon goes as directly as possible where it is required according to the constraints (i.e. field data, mass-balance equations, and inequalities based on previous studies), (2) when several pathways of similar length are possible from one compartment to another, the carbon is evenly shared among them; and (3) the non-necessary carbon as determined by the constraints exits the system by the shortest possible route.

According to the first of these consequences of the parsimony principle, the direct grazing of phytoplankton by mesozooplankton is favored over the grazing of phytoplankton by microzooplankton which is in turn grazed by mesozooplankton. This causes an artificial decrease in the number of trophic levels in the food web, which promotes herbivory. The second consequence implies an equivalent effect of 2 grazer compartments (i.e. micro- and mesozooplankton), whereas a competition leading to one dominating over the other may be more probable. This could be prevented by splitting the grazers' compartments according to their feeding preferences. Finally, the third consequence artificially increases respiration at the lower trophic levels. This is, however, consistent with the general observation of exponentially decreasing respiration rates with increasing sizes (Moloney \& Field 1989). Despite the problems related to the parsimony principle, a final criterion cannot be avoided if a single solution is sought. For the time being, the parsimony principle is the only such criterion that is generally accepted.
In the present study, inverse analysis was applied for the first time to a tropical planktonic system. It was possible to derive the main characteristics of that system from an incomplete data set. The sensitivity analyses showed the model to be robust. Hence, despite possible biases resulting from the parsimony principle, which must be kept in mind, the inverse approach is a powerful tool for obtaining the characteristics of underdetermined systems. This is generally the case for planktonic food webs.

Acknowledgements. We thank the members of the PGRN group, who made their data available, especially L. Charpy, J.-P. Torréton, and R. Le Borgne for helpful remarks. We also thank 4 anonymous reviewers for useful comments and suggestions. This work was supported by a grant from EVAAM (Etablissement pour la Valorisation des Activités Aquacoles et Maritimes). Ministère de la Mer of the French Polynesian Government.

\section{LITERATURE CITED}

Alongi DM (1988) Detritus in coral reef ecosystems: fluxes and fates. Proc 6th Int Symp Coral Reef, Townsville 1: $29-36$

Andrefouët S (1994) Caractérisation des éléments morphologiques des atolls des Tuamotu à partir des données SPOT Mémoire de DEA, Université Française du Pacifique, Papeete

Arias-González JE (1993) Fonctionnement trophique d'un écosystème récifal: secteur de Tiahura, lle de Moorea, Polynésie française. Thèse de Doctorat, Ecole Pratique des Hautes Etudes, Paris

Arias-González JE, Delesalle B, Salvat B, Galzin R (1997) Trophic functioning of the Tiahura reef sector, Moorea Island, French Polynesia. Coral Reefs 16:231-246

Azam F, Fenchel T, Field JG, Gray JS, Meyer-Reil LA, Thingstad F (1983) The ecological role of water-column microbes in the sea. Mar Ecol Prog Ser 10:257-263

Blanchot J, Charpy L, Le Borgne R (1989) Size composition of particulate organic matter in the lagoon of Tikehau atoll (Tuamotu archipelago). Mar Biol 102:329-339

Chardy P, Gros P, Mercier H, Monbet Y (1993) Benthic carbon budget for the Bay of Saint-Brieuc (Western Channel). Application of inverse method. Oceanol Acta 16(5-6): $687-694$

Charpy L (1996) Phytoplankton biomass and production in two Tuamotu atoll lagoons (French Polynesia). Mar Ecol Prog Ser 145:133-142

Charpy L, Blanchot J, Lo L (1992) Contribution des cyanobactéries (Synechococcus spp.) à la production phytoplanctonıque dans un lagon d'atoll fermé (Takapoto, Tuamotu, Polynésie Française). C R Acad Sci Paris Ser III 314: 395-401

Charpy L. Buestel D, Pouvreau S, Cabral P (1994a) Synthèse des recherches sur l'environnement du lagon de Takapoto. Résumé des actions de recherche du PGRN. IFREMER-EVAAM, Tahiti

Charpy L, Charpy-Roubaud C (1990) Trophic structure and productivity of the lagoonal communities of Tikehau atoll (Tuamotu Archipelago, French Polynesia). Hydrobiologia 207:43-52

Charpy L, Dufour P, Garcia N (1997) Particulate organic 
matter in sixteen Tuamotu atoll lagoons (French Polynesia). Mar Ecol Prog Ser 151:55-65

Charpy L, Langy S, Le Borgne R, Lo L, Rochette JP (1994b) Etude de la perte de matière organique particulaire pour la nacre par les compétiteurs planctoniques. Rapport de la fiche 14 du PGRN. IFREMER-EVAAM, Tahiti

Charpy-Roubaud CJ (1988) Production primaire des fonds meubles du lagon de Tikehau (atoll des Tuamotu, Polynésie française). Oceanol Acta 11(3):241-248

Crossland CJ, Hatcher BG, Smith SV (1991) Role of coral reefs in global ocean production. Coral Reefs 10(2):55-64

Darlu P, Tassy P (1993) Reconstruction phylogénétique. Concepts et méthodes. Masson, Paris

Ducklow HW (1990) The biomass, production and fate of bacteria in coral reefs. In: Dubinsky $Z$ (ed) Ecosystems of the world, No. 25, Coral reefs. Elsevier, Amsterdam, p 265-289

Ducklow HW, Fasham MJR, Vézina AF (1989) Derivation and analysis of flow networks for open ocean plankton systems. In: Wulff F, Field JG, Mann KH (eds) Network analysis in marine ecology. Springer-Verlag, Berlin, p 159-205

Eldridge PM, Jackson GA (1992) Benthic food web flows in the Santa Monica Basin estimated using inverse methodology. In: Rowe GT, Pariente V (eds) Deep-sea food chains and the global carbon cycle. Kluwer Academic Publishers, The Netherlands, p 255-276

Eldridge PM, Jackson GA (1993) Benthic trophic dynamics in California coastal basin and continental slope communities inferred using inverse analysis. Mar Ecol Prog Ser 99:115-135

Fenaux R (1989) Les mécanismes de l'alimentation chez les Appendiculaires. Oceanis 15(1):31-37

Furnas MJ (1988) The behavior of nutrients in tropical aquatic ecosystems. In: Connel DW. Hawker DW (eds) Pollution in tropical aquatic systems, Chap 2. CRC Press, London, p 29-65

Gattuso JP, Pichon M, Delesalle B, Frankignoulle M (1993) Community metabolism and air-sea $\mathrm{CO}_{2}$ fluxes in a coral reef ecosystem. Mar Ecol Prog Ser 96:259-267

Gerber RP, Gerber MB (1979) Ingestion of natural particulate organic matter and subsequent assimilation, respiration and growth by tropical lagoon zooplankton. Mar Biol 52:33-43

Gerber RP, Marshall N (1974) Ingestion of detritus by the lagoon pelagic community at Eniwetok Atoll. Limnol Oceanogr 19(5):815-824

Grand S, Hauti A (1993) L'aquaculture nacrière et perlière. In: Atlas de la Polynésie française. ORSTOM edition, Paris, p 282-287

Jackson GA, Eldridge PM (1992) Food web analysis of a planktonic system off Southern California. Prog Oceanogr 30:223-251

Kinsey WD (1985) Metabolism, calcification and carbon production. Proc 5th Int Coral Reef Congr, Tahiti 4:515-526

Le Borgne $\mathrm{R}$, Blanchot J, Charpy L (1989) Zooplankton of Tikehau atoll (Tuamotu archipelago) and its relationship to particulate matter. Mar Biol 102:341-353

Le Borgne R, Rodier M, Le Bouteiller A, Kulbicki M (1997) Plankton biomass and production in an open atoll lagoon: Uvea, New Caledonia. J Exp Mar Biol Ecol 212:187-210

Lewis JB (1977) Processes of organic production on coral reefs. Ecol Rev 52:305-347

Magnier Y, Wauthy B (1976) Esquisse hydrologique du lagon de Takapoto, Tuamotu. Cahiers ORSTOM, Ser Océanogr 14(5):279-287

Marshall N (1965) Detritus over the reef and its potential contribution to adjacent waters of Eniwetok Atoll. Ecology $46(3): 343-344$

Moloney CL, Field JG (1989) General allometric equations for rates of nutrient uptake, ingestion, and respiration in plankton organisms. Limnol Oceanogr 34(7):1290-1299

Morrissey JI (1985) Carbon flow through fleshy macroalgae on coral reefs. PhD thesis, University of Hawaii, Honolulu

Motoda S (1938) Quantitative studies of macroplankton off coral reefs of Palao. Trans Sapporo Nat Soc 15:242-246

Odum HT, Odum EP (1955) Trophic structure and productivity of the windward coral reef community of Eniwetok atoll. Ecol Monogr 25(3):291-320

Opitz S (1993) A quantitative model of the trophic interactions in a Caribbean Coral Reef Ecosystem. In: Christensen V, Pauly D (eds) Trophic models of aquatic ecosystems ICLARM Conf Proc 26. ICLARM, Manila, p 259-26?

Rassoulzadegan F, Sheldon RW (1986) Predator-prey interactions of nanozooplankton and bacteria in an oligotrophic marine environment. Limnol Oceanogr 31(5):1010-1021

Renon JP (1989) Le zooplancton des milieux recifo-lagonaires de Polynésie. Variations spatiales et bilan de production et d'échanges. Thèse d'Etat de l'Université d'Orléans

Ricard M, Gueredrat JA, Magnier Y, Renon JP, Rochette JP, Rougerie F, Sournia A, Wauthy B (1979) Le plancton du lagon de Takapoto. J Soc Océanistes 35(62):47-57

Rougerie F (1979) Caractéristiques générales du milieu liquide lagonaire de l'atoll de Takapoto. J Soc Océanistes 35(62): $35-45$

Rougerie F (1995) Nature et fonctionnement des atolls des Tuamotu (Polynésie française). Oceanol Acta 18(1):61-78

Russel FS (1934) The zooplankton. Sci Rep Great Barrier Reef Exped 2:159-201

Salvat B (1969) Dominance biologique de quelques mollusques dans les atolls fermés (Tuamotu, Polynésie); phénomène récent-conséquences actuelles. Malacologia 9(1):187-189

Salvat B (1976) Un programme interdisciplinaire sur les écosystèmes insulaires en Polynésie française. Cah Pac 19: $397-406$

Salvat B (1988) Bibliographie de l'atoll de Takapoto, Archipel des Tuamotu. Bull Soc Et Océaniennes 243 20(8):55-60

Salvat B, Richard G (1985) Takapoto atoll, Tuamotu archipelago. Proc 5th Int Coral Reef Congr, Tahiti 1:323-378

Sargent MC, Austin TS (1949) Organic productivity of an atoll. Trans Am Geophys Union 30(2):245-249

Sargent MC, Austin TS (1954) Biological economy of coral reefs. Organic productivity of an atoll. US Geol Survey Prof Paper 260-e. US Dept of the Interior, Washington, DC, p 293-301

Sherr BF, Sherr EB (1984) Role of heterotrophic protozoa in carbon and energy flows in aquatic ecosystems. In: Klug MJ, Reddy CA (eds) Current perspectives in microbial ecology. Am Soc Microbiol, Washington, DC, p 412-423

Sherr EB (1988) Direct use of high molecular weight polysaccharide by heterotrophic flagellates. Nature 335:348-351

Sherr EB, Sherr BF (1988) Role of microbes in pelagic food webs: a revised concept. Limnol Oceanogr 33(5):1225-1227

Sorokin YI (1973) Trophical role of bacteria in the ecosystem of the coral reef. Nature 242:415-417

Sorokin YI (1990) Aspects of trophic relations, productivity and energy balance in coral reef ecosystems. In: Dubinsky $Z$ (ed) Ecosystems of the world, No. 25, Coral reefs. Elsevier, Amsterdam, p 401-409

Sournia A (1977) Analyse et bilan de la production primaire dans les récifs coralliens. Ann Inst Océanogr, Paris 53(1): $47-74$

Sournia A, Ricard M (1976) Données sur l'hydrologie et la productivité d'un lagon d'atoll fermé (Takapoto, Tuamotu). Vie Milieu 26:243-279

Torréton JP, Dufour P (1996) Temporal and spatial stability of bacterioplankton biomass and productivity in an atoll lagoon. Aquat Microb Ecol 11(3):251-261 
Torréton JP, Pagès J, Dufour P, Cauwet G (1997) Bacterioplankton carbon growth yield and DOC turnover in some coral reef lagoons. Proc 8th Int Symp Coral Reef, Panama $1: 947-952$

Vézina AF (1989) Construction of flow networks using inverse methods. In: Wulff F, Field JG, Mann KH (eds) Network analysis in marine ecology. Springer-Verlag, Berlin, p $62-81$

Editorial responsibility: Otto Kinne (Editor).

Oldendorf/Luhe, Germany
Vézina AF, Pace ML (1994) An inverse model analysis of planktonic food webs in experimental lakes. Can J Fish Aquat Sci 51(9):2034-2044

Vézina AF, Platt T (1988) Food web dynamics in the oceans. 1. Best-estimates of flow networks using inverse methods. Mar Ecol Prog Ser 42:269-287

Wilkinson CR (1987) Microbial ecology on a coral reef. Search 18(1):31-33

Submitted: August 21, 1997; Accepted: February 20, 1998 Proofs received from author(s): April 9, 1998 